\title{
Dynamic Propagation and Impact of Pandemic Influenza A (2009 H1N1) in Children: A Detailed Review
}

\author{
Yashwant Kumar Ratre ${ }^{1}$. Naveen Kumar Vishvakarma ${ }^{1}$ L. V. K. S. Bhaskar ${ }^{2} \cdot$ Henu Kumar Verma ${ }^{3}$ (I)
}

Received: 31 March 2020 / Accepted: 13 September 2020 / Published online: 21 September 2020

(c) Springer Science+Business Media, LLC, part of Springer Nature 2020

\begin{abstract}
Influenza is a highly contagious respiratory infection caused by the circulating Swine flu virus. According to the World Health Organization (WHO), the unique blending strain of influenza A H1N1 2009 (Swine Flu) is a pandemic affecting several geographical regions, including India. Previous literature indicates that children are "drivers" of influenza pandemics. At present, satisfactory data were not available to accurately estimate the role of children in the spread of influenza (in particular 2009 pandemic influenza). However, the role of children in the spread of pandemics influenza is unclear. Several studies in children have indicated that the immunization program decreased the occurrence of influenza, emphasizing the significance of communities impacted by global immunization programs. This article provides a brief overview on how children are a key contributor to pandemic Influenza A (2009 H1N1) and we would like to draw your attention to the need for a new vaccine for children to improve disease prevention and a positive impact on the community.
\end{abstract}

$\begin{array}{ll}\text { Abbreviations } \\ \text { ALRI } & \text { Acute lower respiratory infections } \\ \text { WHO } & \text { World Health Organizations } \\ \text { HA } & \text { Hemagglutinin } \\ \text { NA } & \text { Neuraminidase } \\ \text { ARDS } & \text { Acute Respiratory Distress Syndrome } \\ \text { ILI } & \text { Influenza-like illness } \\ \text { POCT } & \text { Point of care testing } \\ \text { RIDT } & \text { Rapid influenza diagnostic tests } \\ \text { LAIV } & \text { Attenuated influenza vaccines } \\ \text { IIV } & \text { Inactivated influenza vaccine } \\ \text { ACIP } & \text { Advisory Committee on Immunization Practices } \\ \text { DCGI } & \text { Drug Controller General of India } \\ \text { AAP } & \text { American Academy of Pediatrics } \\ \text { IAV } & \text { Influenza A virus } \\ \text { IBV } & \text { Influenza B virus }\end{array}$

Henu Kumar Verma

henu.verma@yahoo.com; henu.verma@ieos.cnr.it

1 Department of Biotechnology, Guru Ghasidas Vishwavidyalaya, Bilaspur, India

2 Department of Zoology, Guru Ghasidas Vishwavidyalaya, Bilaspur, India

3 Institute of Experimental Endocrinology and Oncology CNR, Naples, Italy

\section{Introduction}

Influenza virus (commonly known as 'flu virus' or 'swine flu virus') is a life-threatening pathogenic circulating virus, preferably infecting the respiratory tract. It has a unique ability to cause a recurrence epidemic and pandemics in individuals of all ages. In growing children, it causes acute lower respiratory infections such as bronchitis and pneumonia [1]. The proportion of hospitalizations for children can reflect the severity of the disease. It is estimated that $10 \%$ of all hospitalizations in children below 18 years of age are due to respiratory diseases and cause $3 \%$ of post-neonatal deaths worldwide [2]. The transmission of influenza contributed to several factors, including the probability of infection, the susceptibility of the population and the risk of contact between highly prone and infected individuals. Swine flu virus is transmitted from person to person mainly through respiratory air droplets caused by the sneezing or coughing of infected persons [3]. Pandemic influenza A (2009 H1N1) is a viral disease that appears with influenza-like symptoms in children and young adults compared to the other adult population.

Unlike other respiratory infections, especially seasonal or recurrent influenza, the clinical severity and pathogenicity recorded with $2009 \mathrm{H} 1 \mathrm{~N} 1$ was slightly milder; still, it is mysterious. A remarkable gene arrangement combining the genetic material from avian, human and swine flu viruses have been observed for this pandemic infection [4]. 
It was assumed that swine are a logical candidate and work as a "mixing vessel" for the novel genetic shift of avian, swine, and human viruses, since they share a common signaling receptor (epitopes) that classifies both strains equally. Thus, swine play a significant role in the occurrence of swine flu viruses as well as in the initiation of human pandemic outbreaks [5].

The first outbreak of H1N1 infection in 2009 originated in California, North America, but was reported in the Mexican village on 18 March 2009 [6]. Subsequently, the extent of the outbreak covered around 10-20\% of the global population and finally switching the human seasonal flu virus (H1N1) [7]. By 11 June 2009, the World Health Organization (WHO) declared it to be the first global pandemic of the twenty-first century and confirmed post-pandemic phases in August 2010. As per the WHO guideline, the 2009 H1N1 virus is currently considered to be a seasonal Swine flu virus [8]. The highest number of hospitalizations was seen among children under the age of five [9].

On the other hand, many empathies depend on studies available in the public domain. All studies have a different sample size, reflecting the accurate estimate of the population attribute; however, they have been over-or underestimated in different age groups. A 2009 study of H1N1 showed that the incidence rate of contact with children is very important for the transmission of the virus in children [10]. Therefore, Pediatric vaccination has been universally implemented with global acceptance as an effective solution to reduce the mortality rate and prevent the spread of 2009 H1N1 [11].

Data from global surveillance and notification systems show a higher risk of $\mathrm{H} 1 \mathrm{~N} 1$ infection in children under two years of age, individuals with underlying medical/clinical conditions and morbidly obese people. Further, low serum level of IgG2 was also associated with the severity of the 2009 H1N1 infection, primarily in pregnant women [12].

The purpose of this review is to provide an overview of the burden of influenza in children worldwide, with a special focus on the $2009 \mathrm{H} 1 \mathrm{~N} 1$ novel strain. The review will also highlight the role of children in the $2009 \mathrm{H} 1 \mathrm{~N} 1 \mathrm{spread}$ (Fig. 1).

\section{Epidemic Status}

Epidemiological studies have shown that the extent of infection with the pathogenic swine flu virus varies from year to year in different geographical regions of the worldwide. Extensive ecological differences are known to influence the prevalence of infection in various populations with varying degrees of severity. Genetic predisposition and lifestyle-mediated risk of infection may also affect the outcome of an epidemic. Available data demand extensive studies covering a diverse areas and age groups at different time periods to recognize the level of H1N1 infection in the community and their spread among various groups of individuals. The novel viral strain of the twenty-first century was first documented in Mexico in April 2009; the virus has spread rapidly to a number of countries around the globe, including India, which has affected more than 214 countries and caused 18,449 deaths in the epidemic [13].

According to a study, about $60 \%$ of patients were under 18 years of age, indicating that young adults were prone to H1N1 infection as compared to older adults. A total of $1,82,166$ clinically established cases of $\mathrm{H} 1 \mathrm{~N} 1$ and 1,800 deaths are reported by WHO [13]. The 2009 H1N1 is less deadly than the other 20th-century outbreaks such as the Spanish flu (H1N1) in 1918, the Asian flu (H2N2) in China in 1957, and the Hong Kong flu (H3N2) in 1968 [14]. It is believed that the Spanish flu was the most serious influenza pandemic and the result of influenza A, which affected about $50 \%$ of the world population and caused about 50 million deaths [15].

In India, 7 million deaths have been reported across different social classes, genders and geographical locations [16]. Up to January 2011, about 46,142 laboratory-confirmed cases and more than 2728 deaths from various parts of the country have been reported in India [17]. The highest incidence of H1N1 2009 was reported in Maharashtra, Madhya Pradesh, Telangana, Karnataka, Jammu \& Kashmir, Rajasthan, Gujarat, Delhi, and Tamil Nadu [18]. The first Indian report of 2009 H1N1 was recorded in June 2009 from Hyderabad City of Telangana State and the first mortality from Pune. Only 937 deaths and 9972 proven cases of pandemic influenza A were reported in Maharashtra [19].

Growing children and young adults were most susceptible to infection and every 2 out of 5 infected children were under 14 years of age. Mortality (27,236 cases) and morbidity (981 deaths) are higher due to the $2009 \mathrm{H} 1 \mathrm{~N} 1$ pandemic in India [20]. At the beginning of 2015, H1N1 2009 re-emerged in India, and more than 2000 deaths from 35,000 recorded cases were reported in mid-February 2015 [19]. Seasonal patterns of influenza in tropical and subtropical countries vary from year to year which is consistent with connectivity, herd immunity, community practices, moisture, indoor swarming, and heat at a particular latitude. High rates of cases have been observed for during the rainy season worldwide. In India, the highest rate of influenza movement was detected during the rainy season [21]. The burden of pandemic influenza in global populations is summarized in Table 1.

\section{Biochemistry and Mechanism of Infection}

Influenza A is a negative-sense ssRNA virus with a spherical or filamentous shape belonging to the orthomyxoviridae family. In addition to the point mutation in this virus, the 


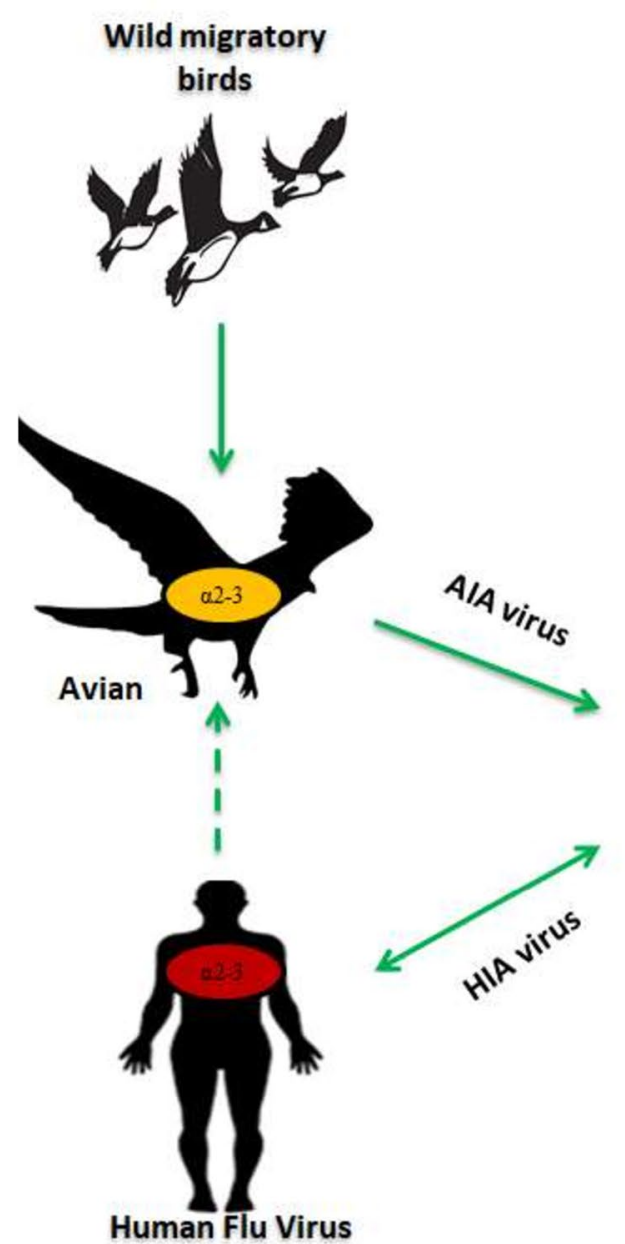

\section{Infect in Children}

Novel SO-IAV (H1N1)
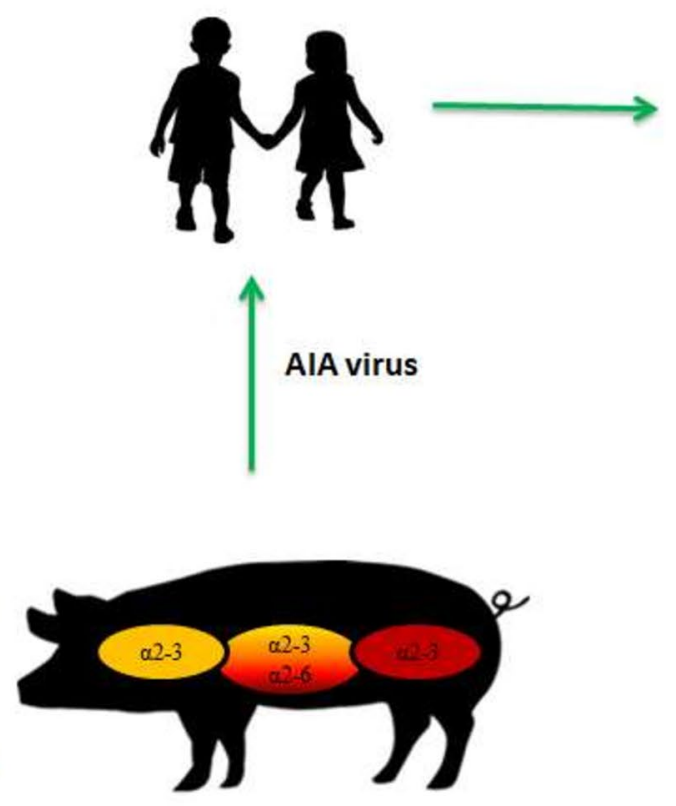
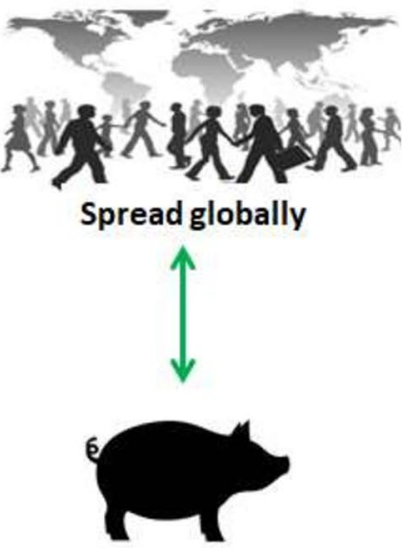

Re-emerge in swine
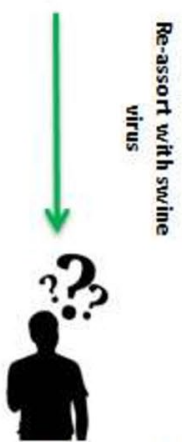

Novel influenza A virus stain?
Fig. 1 The swine is a potential source for reassortment and mixing of influenza A viruses. The antigenic and genetic similarities between avian, human and swine influenza A viruses (IAV) make swine more susceptible to infected by both avian and human influenza strains. IAV from swine can also infect human. Avian and human Swine flu virus glycoprotein (HA) is preferentially binds to $\alpha-2,3$ and $\alpha-2,6$ SA receptors, which are independently expressed on the cells of respiratory track, whereas swine can express both types of SA receptors proving that swine act as a "mixing vessel" for avian and human

genetic reassortment of RNA segments confers a unique ability to alter the host genome and the virulence factor. Swine flu viruses can be categorized on the basis of genetic/ antigenic variations of glycoproteins on their surface, namely hemagglutinin (HA) and neuraminidase (NA). Both HA and NA play a significant role in the pathogenesis of viral disease and act as a significant target for vaccine design. Swine flu virus is multifaceted and involves the spread of different viruses among different animal classes.

Wild duck and shorebirds serve as the usual reservoirs of Swine flu virus. Birds infected with viruses containing combinations of 18 HA (H1-H18) and 11 NA (N1-N11) subtypes. Several aquatic birds act as primary natural reservoirs influenza A viruses and that reassortant virus combination is responsible for the origin of novel pandemic influenza A (2009 H1N1) virus which effect in children age group. Children are highly susceptible to seasonal as well as influenza A infection and play key role in spreading "human to human" influenza infection. Re-entry of human IAV H1N1 to swine may give rise to a novel future influenza A strain which may further leads to pandemic/epidemic. Solid lines: Represent confirmed infection events, Dotted line: Depicted occasional infection event

for low pathogenicity avian Swine flu viruses. In 2014, two novel lines of influenza A virus H17N10 and H18N11 subtypes were detected in rectal swabs of the small yellowshouldered bat and the flat-faced fruit-eating bat [46]. To date, only glycoprotein's subtypes N1, N2 and H1, H2, H3 are known to have positively adapted to humans [47].

Human respiratory cells and avian host cells differently express $\alpha-2,3$, and $\alpha-2,6$ sialic acid receptors, respectively, Swine can express both $\alpha-2,3$ as well as $\alpha-2,6$ sialic acid receptors. Due to the segmented viral genome, when two different types of Swine flu viruses infect the same host it can be interchanged, that generates a novel fusion called 'reassortant'. Such 'reassortant' is a key factor and potential 
Table 1 Pandemic influenza burden in global populations

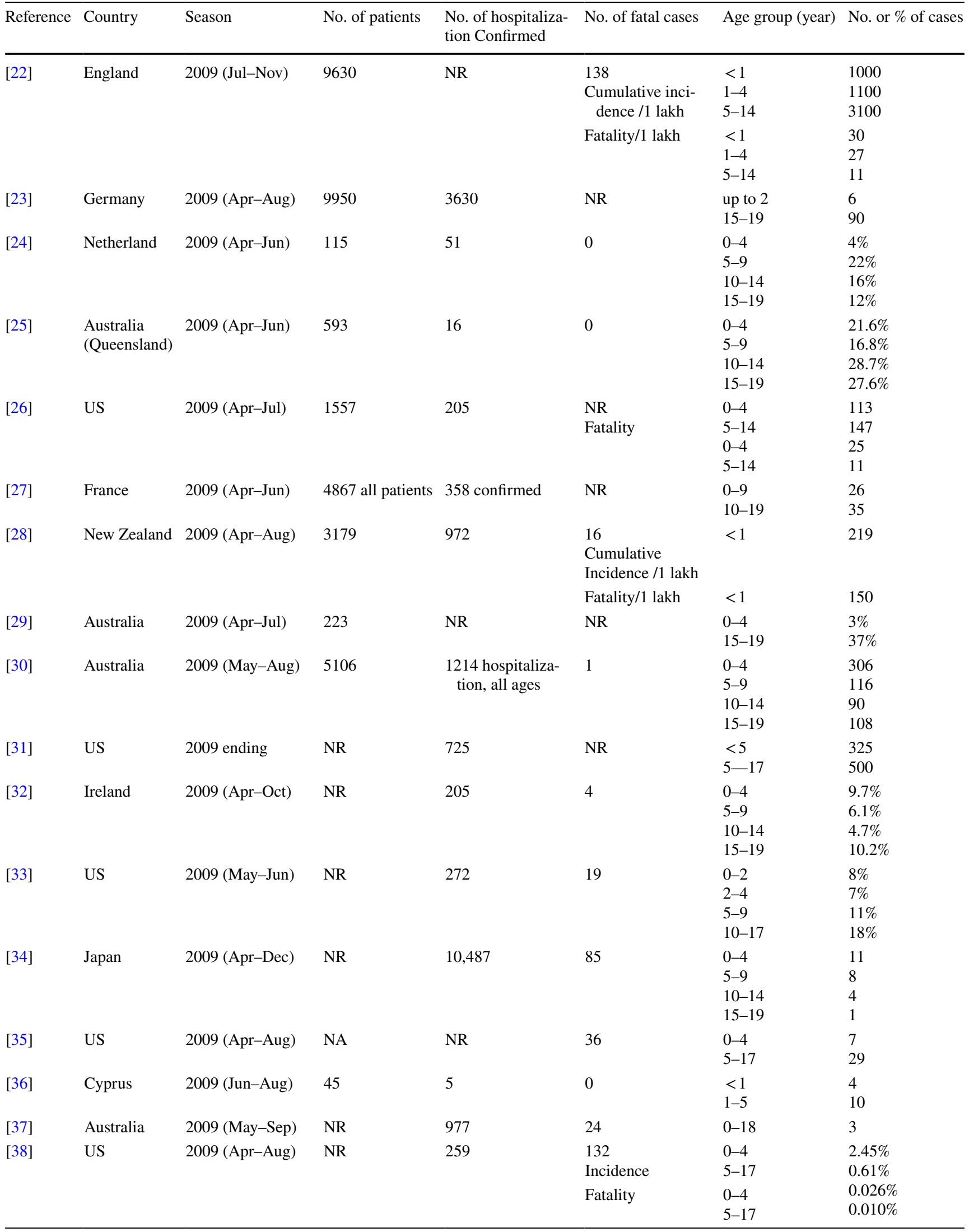


Table 1 (continued)

\begin{tabular}{|c|c|c|c|c|c|c|c|}
\hline Reference & Country & Season & No. of patients & $\begin{array}{l}\text { No. of hospitaliza- } \\
\text { tion Confirmed }\end{array}$ & No. of fatal cases & Age group (year) & No. or $\%$ of cases \\
\hline [39] & France & 2009 (Jul-Nov) & NA & 514 & $\begin{array}{l}\text { Incidence /1 lakh } \\
37 \text { fatality }\end{array}$ & $\begin{array}{l}<1 \\
<1 \\
1-14\end{array}$ & $\begin{array}{l}2.03 \\
3 \\
2\end{array}$ \\
\hline [40] & Canada & 2009 (May-Aug) & 324 & 235 & 2 & $\begin{array}{l}<3 \text { months } \\
3-5 \text { months } \\
6-23 \text { months } \\
2-5 \text { yrs } \\
6-12 \text { yrs } \\
13-15 \text { yrs }\end{array}$ & $\begin{array}{l}15 \\
9 \\
49 \\
66 \\
63 \\
33\end{array}$ \\
\hline [41] & Netherland & 2009 (Jun-Dec) & NA & $\begin{array}{l}2181 \text { hospitaliza- } \\
\text { tions (non-ICU), } \\
\text { all ages }\end{array}$ & $\begin{array}{l}53 \\
\text { Incidence/1 lakh } \\
\text { Fatality }\end{array}$ & $\begin{array}{l}0-4 \\
5-14 \\
0-4 \\
5-14\end{array}$ & $\begin{array}{l}565 \\
350 \\
5 \\
9\end{array}$ \\
\hline [42] & New Zealand & 2009 (May-Oct) & 3254 & 1008 & $\begin{array}{l}\text { Cumulative inci- } \\
\text { dence /1 lakh }\end{array}$ & $\begin{array}{l}<1 \\
1-4 \\
5-9 \\
10-14 \\
15-19\end{array}$ & $\begin{array}{l}223 \\
97 \\
84 \\
92 \\
127\end{array}$ \\
\hline & & & & & Fatality 19/1 lakh & $\begin{array}{l}5-9 \\
10-14 \\
15-19\end{array}$ & $\begin{array}{l}17 \\
19 \\
23\end{array}$ \\
\hline [43] & UK & 2009 (Apr-Sep) & NR & 631 & 29 & $\begin{array}{l}<1 \\
1-4 \\
5-15\end{array}$ & $\begin{array}{l}42 \\
49 \\
125\end{array}$ \\
\hline & & & & & Fatality & $0-15$ & $3.5 \%$ \\
\hline [44] & Canada & 2009 (Apr-Jun) & 3152 & 140 & 7 & $\begin{array}{l}<1 \\
1-11 \\
12-18\end{array}$ & $\begin{array}{l}48 \\
863 \\
880\end{array}$ \\
\hline [45] & England & $\begin{array}{l}\text { 2009-2010 (Apr- } \\
\text { Mar) }\end{array}$ & NA & 440 & 336 & $<1$ & 4 \\
\hline
\end{tabular}

source of 2009 influenza pandemic strains [48]. Swine can serve as host for avian and mammalian adapted strains, and thus conventionally assumed to act as a 'mixing vessel' between them, and facilitating the generation of more precarious and pathogenic novel 'reassortant' Swine flu viruses [49].

Influenza A virus has a segmented genome with capsulated matrix 1 (M1) protein, surrounded by host -derived phospholipid bilayer, which interacts with surface glycoproteins (HA and NA) and viral ribonucleoprotein (vRNP) complexes. The ion channel protein matrix 2 (M2), embedded in the virus envelope membrane which is important for the transport of ions across the viral membrane and budding of new cell surface viruses [50].

As an antigen interaction and a fusion initiator, HA has a number of significant functions in the virus infection cycle. HA mediates the direct binding of the virus to specific terminal sialic acid (SA) on the cell surface and regulates the incorporation of viral genetic material through the membrane fusion process. In contrast, NA protein plays a vital role later in infection by eliminating SA from sialyloligosaccharides, which is essential for releasing newly formed virons from the viral envelope and inhibiting the self-gathering of the virus genome [51].

\section{Children Play a Crucial Role in Propagating Pandemic Influenza}

It has been observed that children are highly susceptible to both seasonal and pandemic influenza. Children of early age have a maximum hospitalization rate and are the primary route of community infection [52, 53]. In terms of severity and burden of disease, the 2009 H1N1 had a significant impact on the pediatric population [54]. Statistics from three influenza pandemics (Hong Kong flu, Asian flu and Spanish flu) reported the highest rates of disease in school-going children, which was also the main source of infection spread among adults [55].

Several other factors also contribute to the vulnerability of children to infection. Children regularly spend time in crowded places, such as schools, playground and after-school 
care, which increases their risk of influenza infection. Such behavioral observation among children contributes disproportionately to the spread of influenza infection and to the amplification of the pandemic. As a result, children are more often and responsible for secondary transmission than adults within their homes.

Many studies have shown the leading role of children in influenza epidemics and pandemics (2009 A/H1N1, 2010-2011 A/H3N2, 2010-2011 A/H1N1, 2012-2013 A/ H3N2 and 2013-2014 A/H1N1) with the highest relative risk ratio (RR) among all age groups [56]. Wardell et al. found that the risk of transmission of an infected first child to another child was $21.9 \%$, [95\% CI 14.5-30.2] higher than the corresponding risk to live with an adult, $11.4 \%$, RR 1.9, 95 per cent CI 1.2-2.8. Compared to children [6.9\%, 95\% CI 4.4-10.1], adults were less likely to contribute to the spread of infection by another adult [0.6, 95\% CI 0.3-0.96] [57].

The decreased frequency of influenza transmission was also reported during school closure periods compared to open-time schools, indicating the crucial role of school children in the spread of influenza [58]. The contributing role of school-going children decreased significantly during the post-pandemic period, which is likely due to the immunity gained during the pandemic. Furthermore, it has been reported that school-aged children (5-17 years of age) have the highest rates of influenza attack during the 2009 H1N1 pandemic [59]. In the US, during annual epidemics between 1977-1978 and 1980-1981, children aged 0-19 years had a higher risk of infection with influenza A compared to adults with influenza A. compared to adults of any age. In addition, influenza B epidemics in the 1976-1977 and 1979-1980 age groups of 5-14 years show the highest risk of infection [60].

\section{Clinical Manifestation and Hospitalization}

Flu causes infection and disease in all age groups of both genders, but children show the highest rates of infection, in particular $40 \%$ higher hospitalizations during epidemics [61-63]. Pandemic influenza A infection in children, typical influenza-like symptoms (ILS) such as cough, sore throat, runny nose, headache, fever, muscle aches, and malaise may vary in severity from mild to severe. Some studies have also reported symptoms of vomiting and diarrhea that are more frequent in children than in other age groups [64]. Pneumonia is the most common complication of pandemic influenza A infection. Forty-five cases of 2009 H1N1 in children aged 40 days to 15 years in the Cyprus region; 5 of them were hospitalized (average time of 3.4 days); no influenza-related deaths and typical clinical symptoms were the same [36]. 79 positive cases of pandemic influenza $\mathrm{A}$, with an average age of 5.7 years have been reported to be hospitalized in Birmingham, UK [65].
In Switzerland, 326 PCR confirmed 2009 H1N1 patients were reported, of which $189(57.97 \%)$ patients were less than 5 years age and $38.65 \%$ of patients had one or more pre-existing clinical condition. Fever was the most common indication of infection; febrile seizures were most recurrent condition in children of less than 5 years of age. However, bacterial infection observed only in $4 \%$ of patients [66].

A serum-based diagnostic study from the USA has shown that most people are likely to be susceptible to $2009 \mathrm{H} 1 \mathrm{~N} 1$ infection, but older people have a certain level of cross-protection against pandemic influenza compared to children in this region [67]. The incidence of $2009 \mathrm{H} 1 \mathrm{~N} 1$ infection in school-going children was reported to be more prevalent in worldwide, ranging from 34 to $43 \%$. Although the results were inconsistent, the Hong Kong study found higher rates of infection in older children, while another study reported higher rates in younger children [68].

An Iranian study reported that about $50-60 \%$ of children with $0-19$ years age had more than 40 titers after pandemic [69]. A study showed that the rate of admission in infant over 6 months of age is similar to that in high-risk adults, but an increased admission rate was found in children more than two years of age [70]. One study from India reported that 85 children were positive for $2009 \mathrm{H} 1 \mathrm{~N} 1$ virus infection; maximum were boys; about $64.7 \%$ were between 5 and 16 year of age. The average age for children was $7.5 \pm 3.5$ years. The mean period of hospitalization was 5.4 days for the children with a reporting of 3 deaths with Acute Respiratory Distress Syndrome [71].

A study reported in the Pune region of Maharashtra, the highest incidence of influenza-associated hospitalizations and deaths among individuals under 35 years of age at the peak of the flu pandemic. Another study conducted in 2007-2010 around Delhi showed that the percentage of influenza A pandemic infection was higher in age groups between 5 and 18 years of age [72]. Influenza infection causes a socio-economic burden due to the loss of school time for children and working time for their family members [73].

\section{Diagnosis}

With the current pandemic influenza A infection and the potential lack of antiviral drugs, especially in developing countries such as India, it is essential for physicians and clinicians to diagnose influenza A cases quickly and precisely. Upper respiratory specimens, including a nasopharyngeal aspirate, a nasal swab plus a throat swab or a nasal wash are collected for $\mathrm{H} 1 \mathrm{~N} 1$ pandemic testing, preferably after 5 days of onset of illness. Rapid diagnostic testing aids in clinical decision-making, reduces improper use of antibiotics and decreases the visit time of the emergency department [74]. 
Techniques and methods used to diagnose and detect seasonal influenza A and B include rapid antigen tests, immunofluorescence antibody tests, viral culture, and RT-PCR. Case definition of infection in a person with influenza-like illness (ILI) confirmed by laboratory diagnosis via RT-PCR and/or viral culture of novel circulating influenza A. The high sensitivity and specificity of RT-PCR makes it a gold standard molecular technique for the diagnosis of pandemic influenza.[75].

Point of care testing can be performed quickly in less than $15 \mathrm{~min}$, which provides a significant time advantage over other laboratory-intensive influenza testing methods. The use of rapid influenza diagnostic tests (RIDTs) may also detect influenza A infection quickly, but Centers for Disease Control and Prevention (CDC) is concerned about the use of RIDT due to their lower sensitivity (ranging from 40 to $69 \%$ ) compared to real-time RT-PCR analyzes [76]. The target population for diagnosis should include individuals who require hospitalization or are at high risk for serious illness. Using the case definition for ILI as a guide to who needs to be tested. However, some groups may have typical clinical presentations, especially infants and children with compromised immune systems requiring influenza A testing.

\section{Antiviral Drugs and Its Clinical Complication}

Antiviral drugs are the main strategies for the effective prevention and control of transmission of influenza. Due to the reassortment of genetic alterations in viral oncoprotein, the virus is more resistant to existing antiviral drugs. It is therefore very important to develop novel, potent, targeted therapeutic drugs to overcome the severity and duration of the disease caused by the pandemic virus. Antiviral drugs are most effective when administered within $24 \mathrm{~h}$ of onset of disease [77].

Two different classes of antiviral drugs such as M2 ion channel protein inhibitors (rimantadine and amantadine) and NA inhibitors (oseltamivir and zanamivir) are currently approved for use against both influenza A and B virus infections. In addition, NA inhibitor drugs inhibit the release of new viral particles from affected cells and mitigate cell-tocell infection, while amantadine and rimantadine block the transport of $\mathrm{H}+$ ions through the viral M2 protein channel that is essential for their entry into the target cell. Traditionally, both drug groups are very effective in managing and preventing seasonal influenza A. Among these, amantadine is recommended for adults only [78].

Oseltamivir (Tamiflu) is the most commonly prescribed oral drug used in seasonal influenza and swine flu infections, which is highly effective for decreasing otitis media incidence in children aged between 1-3 years, when treatment is started within $12 \mathrm{~h}$ of onset of symptoms [79]. Some side effects of drugs have also been reported from various studies. A cross-sectional study in the United Kingdom reported that $18 \%$ of children with oseltamivir treated with influenza A had mild neuropsychiatric side effects and one or more subsequent symptoms such as not being able to concentrate precisely, insomnia, feeling confused nightmares and acting strangely [80]. Another study reported frequent vomiting in oseltamivir-treated children as compared to placebo [81].

U.S. FDA approved zanamivir for use as a dry powder in children aged 5-7 years and old age individuals for management as well as prophylaxis of influenza type A or B virus. According to 74 observational studies this drug is beneficial for the reduction of mortality and influenza-related complications [82]. However, its use is limited to individuals with chronic pulmonary diseases such as asthma. Subsequently, two other classes of NA inhibitor drugs were identified for the management of influenza A and B infections [83]. On the other hand, their use is limited to a few countries, including Japan, China, South Korea and the USA [84, 85].

\section{Vaccination}

Vaccination is a very effective strategy for preventing and controlling influenza infection, particularly in the high-risk population. Infants and children are highly susceptible to infectious diseases and their complications, including pneumonia, due to their frequent activity in crowded settings. Various groups around the globe are looking to vaccines as a potential defense against a novel strain of pandemic influenza A.

Biochemical changes occurring in the Swine flu virus warrant novel immunizations on an annual basis [86]. Generally, two main types of vaccines have been approved to control influenza infection, namely live attenuated influenza vaccines (LAIVs) and inactivated influenza vaccines (IIVs)/ trivalent inactivated vaccines (TIVs) that are US-FDAaccredited for use in children 2 years of age and pregnant women $\geq 50$ years of age. LAIV is administered as a nasal spray, whereas TIV is administered intramuscularly via injection and protects against both influenza $\mathrm{A} / \mathrm{H} 1 \mathrm{~N} 1$ and $\mathrm{A} /$ $\mathrm{H} 3 \mathrm{~N} 2$ strains as well as influenza B viruses [87]. In addition, LAIV provides more effective protection than IIV for infants and children. The Advisory Committee on Immunization Practices (ACIP, CDC), preferably recommends LAIV for children aged 2-8 years when available immediately [ 88 , 89]. Recently approved quadrivalent influenza vaccines (QIVs4) [LAIV FluMist ${ }^{\circledR}$ and three IIV FluarixTM, FluLavalTM and Fluzone $\left.{ }^{\circledR}\right]$ followed in 2012-2013 for people between 2 and 49 years of age, which licensed for Influenza B Yamagata and Victoria lineages but are not allowed to be transported and distributed in India [87]. 
Currently available TIV vaccines are not approved for children under 6 months of age because they may not have a fully mature immune system [88]. Trivalent vaccines, specifically in use, are antigenically homologous to a novel influenza strain. Therefore, this does not require a separate pandemic influenza vaccine. The importance of LAIV marketing and use exists in terms of faster production, a good safety profile, less resource-intensive and cost-effective compared to the inactivated influenza vaccine. In India, after seeing evidence of immunogenicity, quality control and safety in the clinical investigation, pandemic influenza A vaccines have been licensed by the Drug Controller General India (DCGI) and have been available since September 2010 [90]. In the preliminary phase, the Government of India offered $>2.5$ million doses of pandemic influenza to immunize high-risk groups, social and medical staff and emergency unit personnel across India, of whom Karnataka alone used $\sim$ million doses [91].

Current epidemiological data indicate that children and younger adults have been deeply infected with the 2009 pandemic influenza A [92]. Therefore, children should be the primary target group for vaccination. According to the American Academy of Pediatrics, the vaccine must be included in the repetitive immunization regimen for children aged 5 to 18 years [93]. The study showed that LAIV was $82 \%$ effective against pandemic influenza $A$ in children 2-8 years of age and that its efficacy decreased by $11 \%$ in children 9-17 years of age [94].

Recently, the WHO and CDC updated information related to influenza vaccines for the public domain on 28 February 2020 and recommended that all regular dose flu shots be quadrivalent and trivalent for influenza vaccines, including Egg-based Vaccines and Cell-based Recombinant Vaccines for the North of 2020-2021 (https://www.who.int/influenza/ vaccines/virus/recommendations/2020-21_north/en/) and southern hemisphere influenza season (https://www.who. int/influenza/vaccines/virus/candidates_reagents/2020south/ en/).

The vaccine should be made available to the following people at high risk of becoming infected with $\mathrm{H} 1 \mathrm{~N} 1$ swine flu.

1. Children and adults more than six months of age who have a long term health issue, including:

- Chronic liver, kidney, cardiac, pulmonary, neurological diseases, respectively

- Diabetes mellitus

- Children getting a long term of salicylates therapy

2. Pregnant women in all trimesters

3. Immune-compromised people

4. Medical care staff and social workers who have close contact with an infected person

\section{Therapeutic Strategies}

Influenza is a major communicable pandemic disease with a global burden affecting all age groups, especially children and young people. Modern methods used to eradicate pandemic influenza infection include vaccines and antiviral agents such as adamantanes (rimantadine and amantadine) and NA inhibitors (laninamivir, peramivir, oseltamivir, zanamivir). Which oral adamantanes block the M2 ion channel of influenza A virus (IAV) that balances the acidity of the golgi complex microenvironment resulting in the uncoating of the virus. NA inhibitors prohibit the release of virion progeny after budding from the host cell.

Currently, Adamantanes have no action against influenza $B$ virus (IBV) and NA inhibitors have shown activity against both IAV and IBV pathogens [95]. Available therapeutic weapons have limitations, including resistance to highly pathogenic viral strain, prohibitive cost, viral mutation, lack of availability of the desired vaccine due to the time lag between vaccine development and adverse side effects. Unfortunately, none of these drugs have, until recently, been fully capable of impressing on a new pandemic strain of $\mathrm{H} 1 \mathrm{~N} 1$ influenza to eradicate infection.

In addition to this, a new class of anti-influenza drug "baloxavir marboxil" has recently been licensed for the management of both influenza A and B viruses, a mode of action of this drug achieved by inhibiting the endonucleases of the viral polymerase enzyme complex. Although studies have shown that this antiviral compound has a significantly higher effect than Oseltamivir but is only authorized for use in Japan and the USA [96].

Therefore, the researchers also need to emphasize these traditional medicinal herbs, possess natural bioactive compounds that can be used to reduce flu disease and novel pandemic of H1N1 influenza in many geographical locations around the world [97]. Thus, the renovation of strategies for targeting viral surface glycoprotein is significant, because the viral protein is continuously changing its genetic makeup through antigenic variations and making it more potent. Therefore, these proteins are attractive targets for discovering and designing new classes of compounds to stop the progression of the disease. Alternative drugs with new either synthetic or natural bioactive agents are therefore urgently needed for disease mitigation and its related complications (Table 2 ). 
Table 2 Influenza antiviral drugs currently available and under clinical trial [98, 99]

\begin{tabular}{|c|c|c|c|c|c|}
\hline Drug & Generic name & Availability for use & Effective against & Specific Target & Status \\
\hline Oseltamivir & Tamiflu® & Oral & IAV and IBV & \multirow{3}{*}{$\begin{array}{l}\text { Blocks NA protein and } \\
\text { inhibit the release of } \\
\text { virions after budding } \\
\text { from the host cell }\end{array}$} & \multirow[t]{3}{*}{ Approved } \\
\hline Zanamivir & Relenza® & Inhalation & IAV and IBV & & \\
\hline Peramivir & Rapivab® & Intravenous & IAV and IBV & & \\
\hline Amantadine & Symmetrel & \multirow[t]{2}{*}{ Oral } & \multirow[t]{2}{*}{ IAV } & Inhibits viral replication & \multirow{2}{*}{$\begin{array}{l}\text { Approved but currently not } \\
\text { in use due to high resist- } \\
\text { ance to IAV }\end{array}$} \\
\hline Remantadine & Flumadine & & & $\begin{array}{l}\text { by blocking M2 mem- } \\
\text { brane protein }\end{array}$ & \\
\hline Baloxavir marboxil & Xofluza® & Oral & IAV and IBV & $\begin{array}{l}\text { Inhibit the cap-dependent } \\
\text { endonuclease protein }\end{array}$ & Approved \\
\hline Nitazoxanide & Nizonide & Oral & $\begin{array}{l}\text { IAV }(\mathrm{H} 1, \mathrm{H} 3, \mathrm{H} 5, \mathrm{H} 7) \text { and } \\
\text { IBV }\end{array}$ & $\begin{array}{l}\text { Inhibits replication of } \\
\text { virus by vitiate the traf- } \\
\text { ficking of the HA protein } \\
\text { from the endoplasmic } \\
\text { reticulum to the Golgi } \\
\text { complex }\end{array}$ & Under clinical trial phase III \\
\hline DAS181 & Fludase ${ }^{\circledR}$ & Oral/inhalation & $\begin{array}{l}\text { (H1N1)pdm09, H3N2, } \\
\text { H7N9, H5N1 and IBV }\end{array}$ & $\begin{array}{l}\text { Remove silaic acid recep- } \\
\text { tor from host and block } \\
\text { the binding and entry of } \\
\text { virus to the host cell }\end{array}$ & Phase I,II \\
\hline T705 & favipiravir & Oral & IAV, IBV and ICV & $\begin{array}{l}\text { Inhibitor of RNA depend- } \\
\text { ent RNA polymerase }\end{array}$ & Phase II, III \\
\hline
\end{tabular}

\section{Conclusion}

Through a comprehensive analysis, we have identified that children are at significantly higher risk of developing influenza infection as a result of all global pandemics. Therefore, the rate of medical facilities in hospitalization, treatment and ICU care must be increase year by year for children. Together with adult individuals in different settings, this in-depth review suggests that children may have played a significant role in facilitating the transmission of novel pandemics H1N1 influenza. The identification of children as a key "driver" group in propagating pandemic H1N1influenza is of much interest in the implementation of public health response strategies, including social distancing effort, useful antiviral drugs, and vaccination programs.

Author Contributions HKV conceived the study. YKR and NKV collected data. YKR, HKV,BLVKS and NKV wrote the manuscript. All authors have read and approved the manuscript.

\section{Compliance with Ethical Standards}

Conflict of interest The authors declare no conflict of interest.

Consent for Publication All the authors have read the manuscript and have approved this submission.

\section{References}

1. Wang X, Li Y, O’Brien KL, Madhi SA, Widdowson MA et al (2020) Global burden of respiratory infections associated with seasonal influenza in children under 5 years in 2018: a systematic review and modelling study. Lancet Glob Health 8(4):e497e510. https://doi.org/10.1016/S2214-109X(19)30545-5

2. Lozano R, Naghavi M, Foreman K, Lim S, Shibuya K et al (2012) Global and regional mortality from 235 causes of death for 20 age groups in 1990 and 2010: a systematic analysis for the Global Burden of Disease Study 2010. Lancet 380(9859):20952128. https://doi.org/10.1016/S0140-6736(12)61728-0

3. Saunders-Hastings PR, Krewski D (2016) Reviewing the history of pandemic influenza: understanding patterns of emergence and transmission. Pathogens. https://doi.org/10.3390/patho gens5040066

4. Shu B, Garten R, Emery S, Balish A, Cooper L et al (2012) Genetic analysis and antigenic characterization of swine origin influenza viruses isolated from humans in the United States, 1990-2010. Virology 422(1):151-160. https://doi.org/10.1016/j. virol.2011.10.016

5. Chastagner A, Bonin E, Fablet C, Quéguiner S, Hirchaud E et al (2019) Virus persistence in pig herds led to successive reassortment events between swine and human influenza A viruses, resulting in the emergence of a novel triple-reassortant swine influenza virus. Vet Res 50(1):77. https://doi.org/10.1186/s1356 7-019-0699-y

6. Dawood FS, Jain S, Finelli L, Shaw MW, Lindstrom S et al (2009) Emergence of a novel swine-origin influenza A (H1N1) virus in humans. N Engl J Med 360(25):2605-2615. https://doi. org/10.1056/NEJMoa0903810 
7. Cheng VC, To KK, Tse H, Hung IF, Yuen KY (2012) Two years after pandemic influenza A/2009/H1N1: what have we learned? Clin Microbiol Rev 25(2):223-263. https://doi.org/10.1128/ CMR.05012-11

8. Maurer J, Harris KM, Parker AM (2012) Who knew? Awareness of being recommended for influenza vaccination among U.S. adults. Influenza Other Respir Viruses 6(4):284-290. https:// doi.org/10.1111/j.1750-2659.2011.00305.x

9. Fraser C, Donnelly CA, Cauchemez S, Hanage WP, Van Kerkhove MD et al (2009) Pandemic potential of a strain of influenza A (H1N1): early findings. Science 324(5934):1557-1561. https ://doi.org/10.1126/science.1176062

10. Oner AF, Dogan N, Gasimov V, Adisasmito W, Coker R et al (2012) H5N1 avian influenza in children. Clin Infect Dis 55(1):26-32. https://doi.org/10.1093/cid/cis295

11. Henry C, Palm AE, Krammer F, Wilson PC (2018) From original antigenic sin to the universal influenza virus vaccine. Trends Immunol 39(1):70-79. https://doi.org/10.1016/j.it.2017.08.003

12. Chan JF, To KK, Tse H, Lau CC, Li IW et al (2011) The lower serum immunoglobulin $\mathrm{G} 2$ level in severe cases than in mild cases of pandemic H1N1 2009 influenza is associated with cytokine dysregulation. Clin Vaccine Immunol 18(2):305-310. https://doi.org/10.1128/CVI.00363-10

13. Valero-Pacheco N, Perez-Toledo M, Villasis-Keever MA, Nunez-Valencia A, Bosco-Garate I, Lozano-Dubernard B et al (2016) Antibody persistence in adults two years after vaccination with an H1N1 2009 pandemic influenza virus-like particle vaccine. PLoS ONE 11(2):e0150146. https://doi.org/10.1371/ journal.pone. 0150146

14. Smith RD, Keogh-Brown MR, Barnett T, Tait J (2009) The economy-wide impact of pandemic influenza on the UK: a computable general equilibrium modelling experiment. BMJ 339:b4571. https://doi.org/10.1136/bmj.b4571

15. Hayashi Y, Vaska VL, Baba H, Nimmo GR, Davis L et al (2012) Influenza-associated bacterial pathogens in patients with 2009 influenza A (H1N1) infection: impact of community-associated methicillin-resistant Staphylococcus aureus in Queensland. Aust Intern Med J 42(7):755-760. https://doi.org/10.11 11/j.1445-5994.2011.02602.x

16. Nelson MI, Wentworth DE, Culhane MR, Vincent AL, Viboud $C$ et al (2014) Introductions and evolution of human-origin seasonal influenza A viruses in multinational swine populations. J Virol 88(17):10110-10119. https://doi.org/10.1128/jvi.01080 $-14$

17. Choudhry A, Singh S, Khare S, Rai A, Rawat DS, Aggarwal RK, Chauhan LS (2012) Emergence of pandemic 2009 influenza A H1N1, India. The Indian journal of medical research 135(4):534-537

18. Murhekar M, Mehendale S (2016) The 2015 influenza A (H1N1) pdm09 outbreak in India. Indian J Med Res 143(6):821-823. https ://doi.org/10.4103/0971-5916.192077

19. Mishra B (2015) 2015 Resurgence of influenza A (H1N1) 09: smoldering pandemic in India? J Glob Infect Dis 7(2):56-59. https ://doi.org/10.4103/0974-777X.157236

20. Singhal S, Sarda N, Arora R, Punia N, Jain A (2014) Clinical profile \& outcome of H1N1 infected pregnant women in a tertiary care teaching hospital of northern India. Indian J Med Res 139(3):454-458

21. Chadha MS, Potdar VA, Saha S, Koul PA, Broor S et al (2015) Dynamics of influenza seasonality at sub-regional levels in India and implications for vaccination timing. PLoS ONE 10(5):e0124122. https://doi.org/10.1371/journal.pone.0124122

22. Donaldson LJ, Rutter PD, Ellis BM, Greaves FE, Mytton OT et al (2009) Mortality from pandemic A/H1N1 2009 influenza in England: public health surveillance study. BMJ 339:b5213. https://doi. org/10.1136/bmj.b5213
23. Gilsdorf A, Poggensee G, Working Group Pandemic Influenza A (2009) Influenza A(H1N1)v in Germany: the first 10,000 cases. Euro Surveill. https://doi.org/10.2807/ese.14.34.19318

24. Hahne S, Donker T, Meijer A, Timen A, van Steenbergen J et al (2009) Epidemiology and control of influenza A(H1N1)v in the Netherlands: the first 115 cases. Euro Surveill. https://doi. org/10.2807/ese.14.27.19267

25. Appuhamy RD, Beard FH, Phung HN, Selvey CE, Birrell FA et al (2010) The changing phases of pandemic (H1N1) 2009 in Queensland: an overview of public health actions and epidemiology. Med J Aust 192(2):94-97

26. Ritger C (2009) 2009 Pandemic influenza A (H1N1) virus infections April--July

27. Levy-Bruhl D, Vaux S (2009) Modified surveillance of influenza $\mathrm{A}(\mathrm{H} 1 \mathrm{~N} 1)$ virus infections in France. Euro Surveill. https://doi. org/10.2807/ese.14.29.19276-en

28. Baker MG, Wilson N, Huang QS, Paine S, Lopez L et al (2009) Pandemic influenza $\mathrm{A}(\mathrm{H} 1 \mathrm{~N} 1)$ in New Zealand: the experience from April to August 2009. Euro Surveill. https://doi.org/10.2807/ ese.14.34.19319-en

29. Kelly H, Grant K (2009) Interim analysis of pandemic influenza (H1N1) 2009 in Australia: surveillance trends, age of infection and effectiveness of seasonal vaccination. Euro Surveill. https:// doi.org/10.2807/ese.14.31.19288-en

30. New South Wales public health (2009) Progression and impact of the first winter wave of the 2009 pandemic H1N1 influenza in New South Wales, Australia. Euro Surveillance. https://doi. org/10.2807/ese.14.42.19365-en

31. Reed C, Katz JM, Hancock K, Balish A, Fry AM et al (2012) Prevalence of seropositivity to pandemic influenza A/H1N1 virus in the United States following the 2009 pandemic. PLoS ONE 7(10):e48187. https://doi.org/10.1371/journal.pone.0048187

32. Cullen G, Martin J, O'Donnell J, Boland M, Canny M, et al. (2009) Surveillance of the first 205 confirmed hospitalised cases of pandemic H1N1 influenza in Ireland, 28 April - 3 October 2009. Euro Surveill 14(44)

33. Jain S, Kamimoto L, Bramley AM, Schmitz AM, Benoit SR et al (2009) Hospitalized patients with 2009 H1N1 influenza in the United States, April-June 2009. N Engl J Med 361(20):19351944. https://doi.org/10.1056/NEJMoa0906695

34. Kamigaki T, Oshitani H (2009) Epidemiological characteristics and low case fatality rate of pandemic (H1N1) 2009 in Japan. PLoS Curr 1:RRN1139. https://doi.org/10.1371/currents.RRN11 39

35. CDC (2009) Surveillance for pediatric deaths associated with 2009 pandemic Influenza A (H1N1) virus infection (April-August 2009)

36. Koliou M, Soteriades ES, Toumasi MM, Demosthenous A, Hadjidemetriou A (2009) Epidemiological and clinical characteristics of influenza $\mathrm{A}(\mathrm{H} 1 \mathrm{~N} 1) \mathrm{v}$ infection in children: The first 45 cases in Cyprus, June - August 2009. Euro Surveill. https://doi. org/10.2807/ese.14.33.19312-en

37. Fielding J, Higgins N, Gregory J, Grant K, Catton M et al (2009) Pandemic H1N1 influenza surveillance in Victoria, Australia, April - September, 2009. Euro Surveill. https://doi.org/10.2807/ ese.14.42.19368-en

38. Presanis AM, Lipsitch M, Daniela De A, Swine Flu Investigation Team NYCDoH, Mental H, et al. (2009) The severity of pandemic H1N1 influenza in the United States, April - July 2009. PLoS Curr 1:RRN1042. https://doi.org/10.1371/currents.RRN1042

39. Fuhrman C, Bonmarin I, Paty AC, Duport N, Chiron E et al (2010) Severe hospitalised 2009 pandemic influenza $\mathrm{A}(\mathrm{H} 1 \mathrm{~N} 1)$ cases in France, 1 July-15 November 2009. Euro Surveill. https://doi. org/10.2807/ese.15.02.19463-en

40. Bettinger JA, Sauve LJ, Scheifele DW, Moore D, Vaudry W et al (2010) Pandemic influenza in Canadian children: a summary of 
hospitalized pediatric cases. Vaccine 28(18):3180-3184. https ://doi.org/10.1016/j.vaccine.2010.02.044

41. vant Klooster TM, Wielders CC, Donker T, Isken L, Meijer A et al (2010) Surveillance of hospitalisations for 2009 pandemic influenza $\mathrm{A}(\mathrm{H} 1 \mathrm{~N} 1)$ in the Netherlands, 5 June - 31 December 2009. Euro Surveill. https://doi.org/10.2807/ese.15.02.19461-en

42. Paine S, Mercer GN, Kelly PM, Bandaranayake D, Baker MG et al. (2010) Transmissibility of 2009 pandemic influenza $\mathrm{A}(\mathrm{H} 1 \mathrm{~N} 1)$ in New Zealand: effective reproduction number and influence of age, ethnicity and importations. Euro Surveill 15(24)

43. Nguyen-Van-Tam JS, Openshaw PJ, Hashim A, Gadd EM, Lim WS et al (2010) Risk factors for hospitalisation and poor outcome with pandemic A/H1N1 influenza: United Kingdom first wave (May-September 2009). Thorax 65(7):645-651. https://doi. org/10.1136/thx.2010.135210

44. Tuite AR, Greer AL, Whelan M, Winter AL, Lee B et al (2010) Estimated epidemiologic parameters and morbidity associated with pandemic H1N1 influenza. CMAJ 182(2):131-136. https:// doi.org/10.1503/cmaj.091807

45. Pebody RG, McLean E, Zhao H, Cleary P, Bracebridge $\mathrm{S}$ et al. (2010) Pandemic Influenza A (H1N1) 2009 and mortality in the United Kingdom: risk factors for death, April 2009 to March 2010. Euro Surveill 15(20)

46. Byrd-Leotis L, Liu R, Bradley KC, Lasanajak Y, Cummings SF et al (2014) Shotgun glycomics of pig lung identifies natural endogenous receptors for influenza viruses. Proc Natl Acad Sci USA 111(22):E2241-2250. https://doi.org/10.1073/pnas.13231 62111

47. Pietrzak M, Maciola A, Zdanowski K, Protas-Klukowska AM, Olszewska $M$ et al (2016) An avian influenza H5N1 virus vaccine candidate based on the extracellular domain produced in yeast system as subviral particles protects chickens from lethal challenge. Antivir Res 133:242-249. https://doi.org/10.1016/j.antiv iral.2016.08.001

48. Bergervoet SA, Heutink R, Bouwstra R, Fouchier RAM, Beerens N (2019) Genetic analysis identifies potential transmission of low pathogenic avian influenza viruses between poultry farms. Transbound Emerg Dis. https://doi.org/10.1111/tbed.13199

49. Torremorell M, Allerson M, Corzo C, Diaz A, Gramer M (2012) Transmission of influenza A virus in pigs. Transbound Emerg Dis 59(Suppl 1):68-84. https://doi.org/10.111 1/j.1865-1682.2011.01300.x

50. Gamblin SJ, Skehel JJ (2010) Influenza hemagglutinin and neuraminidase membrane glycoproteins. J Biol Chem 285(37):2840328409. https://doi.org/10.1074/jbc.R110.129809

51. Samji T (2009) Influenza A: understanding the viral life cycle. Yale J Biol Med 82(4):153-159

52. Carr S (2012) Seasonal and pandemic influenza: an overview with pediatric focus. Adv Pediatr 59(1):75-93. https://doi. org/10.1016/j.yapd.2012.04.016

53. Elliott EJ, Zurynski YA, Walls T, Whitehead B, Gilmour R et al (2012) Novel inpatient surveillance in tertiary paediatric hospitals in New South Wales illustrates impact of first-wave pandemic influenza A H1N1 (2009) and informs future health service planning. J Paediatr Child Health 48(3):235-241. https://doi.org/10.1 111/j.1440-1754.2011.02240.x

54. Khandaker G, Zurynski Y, Ridley G, Buttery J, Marshall H et al (2014) Clinical epidemiology and predictors of outcome in children hospitalised with influenza $\mathrm{A}(\mathrm{H} 1 \mathrm{~N} 1)$ pdm09 in 2009: a prospective national study. Influenza Other Respir Viruses 8(6):636645. https://doi.org/10.1111/irv.12286

55. Nickol ME, Kindrachuk J (2019) A year of terror and a century of reflection: perspectives on the great influenza pandemic of 1918-1919. BMC Infect Dis 19(1):117. https://doi.org/10.1186/ s12879-019-3750-8
56. Worby CJ, Chaves SS, Wallinga J, Lipsitch M, Finelli L et al (2015) On the relative role of different age groups in influenza epidemics. Epidemics 13:10-16. https://doi.org/10.1016/j.epide m.2015.04.003

57. Wardell R, Prem K, Cowling BJ, Cook AR (2017) The role of symptomatic presentation in influenza A transmission risk. Epidemiol Infect 145(4):723-727. https://doi.org/10.1017/S095026881 6002740

58. Huang KE, Lipsitch M, Shaman J, Goldstein E (2014) The US 2009 A(H1N1) influenza epidemic: quantifying the impact of school openings on the reproductive number. Epidemiology 25(2):203-206. https://doi.org/10.1097/EDE.0000000000000055

59. Ruf BR, Knuf M (2014) The burden of seasonal and pandemic influenza in infants and children. Eur J Pediatr 173(3):265-276. https://doi.org/10.1007/s00431-013-2023-6

60. Walker GJ, Stelzer-Braid S, Shorter C, Honeywill C, Wynn M, Willenborg C, Barnes P, Kang J, Pierse N, Crane J, HowdenChapman P, Rawlinson WD (2019) Viruses associated with acute respiratory infection in a community-based cohort of healthy New Zealand children. J Med Virol. https://doi.org/10.1002/jmv.25493

61. Bender JM, Ampofo K, Gesteland P, Sheng X, Korgenski K et al (2010) Influenza virus infection in infants less than three months of age. Pediatr Infect Dis J 29(1):6-9. https://doi.org/10.1097/ INF.0b013e3181b4b950

62. Cowling BJ, Kwan MY, Wong JS, Feng S, Leung CW et al (2017) Interim estimates of the effectiveness of influenza vaccination against influenza-associated hospitalization in children in Hong Kong, 2015-16. Influenza Other Respir Viruses 11(1):61-65. https://doi.org/10.1111/irv.12399

63. Chiu SS, Lo JY, Chan KH, Chan EL, So LY et al (2014) Population-based hospitalization burden of influenza a virus subtypes and antigenic drift variants in children in Hong Kong (20042011). PLoS ONE 9(4):e92914. https://doi.org/10.1371/journ al.pone.0092914

64. Krog JS, Hjulsager CK, Larsen MA, Larsen LE (2017) Triplereassortant influenza A virus with $\mathrm{H} 3$ of human seasonal origin, NA of swine origin, and internal A(H1N1) pandemic 2009 genes is established in Danish pigs. Influenza Other Respir Viruses 11(3):298-303. https://doi.org/10.1111/irv.12451

65. Hackett S, Hill L, Patel J, Ratnaraja N, Ifeyinwa A et al (2009) Clinical characteristics of paediatric $\mathrm{H} 1 \mathrm{~N} 1$ admissions in Birmingham. UK Lancet 374(9690):605. https://doi.org/10.1016/ S0140-6736(09)61511-7

66. Hagerman A, Posfay-Barbe KM, Duppenthaler A, Heininger U, Berger $C$ et al (2015) Clinical characteristics and outcomes in children hospitalised with pandemic influenza A/H1N1/09 virus infection - a nationwide survey by the Pediatric Infectious Diseases Group of Switzerland. Swiss Med Wkly 145:w14171. https ://doi.org/10.4414/smw.2015.14171

67. Uno S, Kimachi K, Matsuo F, Miyazaki K, Oohama A et al (2012) Cross-reactive antibody response to the pandemic A (H1N1) 2009 influenza virus induced by vaccination with a seasonal trivalent influenza vaccine: a longitudinal study of three influenza seasons in Japan. Microbiol Immunol 56(12):810-816. https://doi.org/10 .1111/j.1348-0421.2012.00511.x

68. Kelly H, Peck HA, Laurie KL, Wu P, Nishiura H et al (2011) The age-specific cumulative incidence of infection with pandemic influenza H1N1 2009 was similar in various countries prior to vaccination. PLoS ONE 6(8):e21828. https://doi.org/10.1371/ journal.pone.0021828

69. Moghadami M (2017) A narrative review of influenza: a seasonal and pandemic disease. Iran J Med Sci 42(1):2-13

70. Zhou B, Meliopoulos VA, Wang W, Lin X, Stucker KM et al (2016) Reversion of cold-adapted live attenuated influenza vaccine into a pathogenic virus. J Virol 90(19):8454-8463. https:// doi.org/10.1128/jvi.00163-16 
71. Das RR, Sami A, Lodha R, Jain R, Broor S et al (2011) Clinical profile and outcome of swine flu in Indian children. Indian Pediatr 48(5):373-378

72. Broor S, Krishnan A, Roy DS, Dhakad S, Kaushik S et al (2012) Dynamic patterns of circulating seasonal and pandemic A(H1N1) pdm09 influenza viruses from 2007-2010 in and around Delhi. India PLoS ONE 7(1):e29129. https://doi.org/10.1371/journ al.pone.0029129

73. Klepser ME (2014) Socioeconomic impact of seasonal (epidemic) influenza and the role of over-the-counter medicines. Drugs 74(13):1467-1479. https://doi.org/10.1007/s40265-014-0245-1

74. Benirschke RC, McElvania E, Thomson RB, Kaul KL, Das S (2019) Clinical impact of rapid point-of-care PCR influenza testing in an urgent care setting: a single-center study. J Clin Microbiol 57(3):e01281-e11218. https://doi.org/10.1128/jcm.01281-18

75. Rodriguez A, Alvarez-Rocha L, Sirvent JM, Zaragoza R, Nieto M et al (2012) Recommendations of the Infectious Diseases Work Group (GTEI) of the Spanish Society of Intensive and Critical Care Medicine and Coronary Units (SEMICYUC) and the Infections in Critically Ill Patients Study Group (GEIPC) of the Spanish Society of Infectious Diseases and Clinical Microbiology (SEIMC) for the diagnosis and treatment of influenza A/H1N1 in seriously ill adults admitted to the Intensive Care Unit. Med Intensiv 36(2):103-137. https://doi.org/10.1016/j.medin.2011.11.020

76. Peci A, Winter AL, King EC, Blair J, Gubbay JB (2014) Performance of rapid influenza diagnostic testing in outbreak settings. J Clin Microbiol 52(12):4309-4317. https://doi.org/10.1128/ JCM.02024-14

77. Reynolds JJ, Torremorell M, Craft ME (2014) Mathematical modeling of influenza A virus dynamics within swine farms and the effects of vaccination. PLoS ONE 9(8):e106177. https://doi. org/10.1371/journal.pone.0106177

78. Alves Galvao MG, Rocha Crispino Santos MA, Alves da Cunha AJ (2014) Amantadine and rimantadine for influenza A in children and the elderly. Cochrane Database Syst Rev. https://doi. org/10.1002/14651858.CD002745.pub4

79. Heinonen S, Silvennoinen H, Lehtinen P, Vainionpaa R, Vahlberg $T$ et al (2010) Early oseltamivir treatment of influenza in children 1-3 years of age: a randomized controlled trial. Clin Infect Dis 51(8):887-894. https://doi.org/10.1086/656408

80. Smith LE, D'Antoni D, Jain V, Pearce JM, Weinman J, Rubin GJ (2016) A systematic review of factors affecting intended and actual adherence with antiviral medication as treatment or prophylaxis in seasonal and pandemic flu. Influenza Other Respir Viruses 10(6):462-478. https://doi.org/10.1111/irv.12406

81. Wang K, Shun-Shin M, Gill P, Perera R, Harnden A (2012) Neuraminidase inhibitors for preventing and treating influenza in children. Cochrane Database Syst Rev. https://doi.org/10.1002/14651 858.CD002744.pub3

82. Hsu J, Santesso N, Mustafa R, Brozek J, Chen YL et al (2012) Antivirals for treatment of influenza: a systematic review and meta-analysis of observational studies. Ann Intern Med 156(7):512-524. https://doi.org/10.7326/0003-4819-156-7-20120 4030-00411

83. De Clercq E (2013) Antivirals: past, present and future. Biochem Pharmacol 85(6):727-744. https://doi.org/10.1016/j. bcp.2012.12.011

84. McLaughlin MM, Skoglund EW, Ison MG (2015) Peramivir: an intravenous neuraminidase inhibitor. Expert Opin Pharmacother 16(12):1889-1900. https://doi.org/10.1517/14656566.2015.10663 36

85. Li TC, Chan MC, Lee N (2015) Clinical implications of antiviral resistance in influenza. Viruses 7(9):4929-4944. https://doi. org/10.3390/v7092850

86. Chung JR, Flannery B, Ambrose CS, Bégué RE, Caspard H, DeMarcus L, Fowlkes AL, Kersellius G, Steffens A, Fry AM
(2019) Live attenuated and inactivated influenza vaccine effectiveness. Pediatrics 143(2):e20182094. https://doi.org/10.1542/ peds.2018-2094

87. Muruganathan A, Guha S, Munjal YP, Agarwal SS, Parikh KK et al (2016) Recommendations for vaccination against seasonal influenza in adult high risk groups: South Asian Recommendations. J Assoc Phys India 64(7 Suppl):3-11

88. Lewnard JA, Cobey S (2018) Immune history and influenza vaccine effectiveness. Vaccines (Basel) 6(2):28. https://doi. org/10.3390/vaccines6020028

89. Grohskopf LA, Sokolow LZ, Broder KR, Walter EB, Fry AM et al (2018) Prevention and control of seasonal influenza with vaccines: recommendations of the advisory committee on immunization practices-United States, 2018-19 influenza season. MMWR Recomm Rep 67(3):1-20. https://doi.org/10.15585/mmwr.rr670 3a1

90. Kulkarni PS, Agarkhedkar S, Lalwani S, Bavdekar AR, Jog S et al (2014) Effectiveness of an Indian-made attenuated influenza A(H1N1) pdm 2009 vaccine: a case control study. Hum Vaccines Immunother 10(3):566-571. https://doi.org/10.4161/hv.27490

91. Holla VN, Borker S (2012) H1N1 newer vaccine usage: experiences from Karnataka State. Indian J Community Med 37(2):134 136. https://doi.org/10.4103/0970-0218.96108

92. Mehta AA, Kumar VA, Nair SG, Joseph FK, Kumar G et al (2013) Clinical profile of patients admitted with swine-origin influenza A (H1N1) virus infection: an experience from a tertiary care hospital. J Clin Diagn Res 7(10):2227-2230. https://doi.org/10.7860/ JCDR/2013/5657.3477

93. Grohskopf LA, Olsen SJ, Sokolow LZ, Bresee JS, Cox NJ et al (2014) Prevention and control of seasonal influenza with vaccines: recommendations of the Advisory Committee on Immunization Practices (ACIP)-United States, 2014-15 influenza season. MMWR Morb Mortal Wkly Rep 63(32):691-697

94. Ohmit SE, Petrie JG, Malosh RE, Johnson E, Truscon R et al (2016) Substantial influenza vaccine effectiveness in households with children during the 2013-2014 influenza season, when 2009 pandemic influenza $\mathrm{A}(\mathrm{H} 1 \mathrm{~N} 1)$ virus predominated. J Infect Dis 213(8):1229-1236. https://doi.org/10.1093/infdis/jiv563

95. Park J-G, Ávila-Pérez G, Nogales A, Blanco-Lobo P, de la Torre JC et al (2020) Identification and characterization of novel compounds with broad-spectrum antiviral activity against influenza A and B viruses. J Virol 94(7):e02149-e12119. https://doi. org/10.1128/jvi.02149-19

96. Hayden FG, Sugaya N, Hirotsu N, Lee N, de Jong MD et al (2018) Baloxavir marboxil for uncomplicated influenza in adults and adolescents. N Engl J Med 379(10):913-923. https://doi.org/10.1056/ NEJMoa1716197

97. Mousa HA-L (2017) Prevention and treatment of influenza, influenza-like illness, and common cold by herbal, complementary, and natural therapies. J Evid Complement Altern Med 22(1):166174. https://doi.org/10.1177/2156587216641831

98. Amarelle L, Lecuona E, Sznajder JI (2017) Anti-influenza treatment: drugs currently used and under development. Arch Bronconeumol 53(1):19-26. https://doi.org/10.1016/j.arbre s.2016.07.004

99. Hurt AC (2019) Antiviral therapy for the next influenza pandemic. Trop Med Infect Dis. https://doi.org/10.3390/tropicalmed4020067

Publisher's Note Springer Nature remains neutral with regard to jurisdictional claims in published maps and institutional affiliations. 